\title{
The Prevalence and Demography of Insufficient Earnings
}

\author{
Dennis H. Sullivan \\ Miami University, Ohio
}

\author{
Andrea L. Ziegert \\ Denison University
}

This research measures the prevalence and demography of full-year full-time workers whose earnings in 2018 or 2019 were insufficient to exceed the Supplemental Poverty Measure (SPM) poverty thresholds. Earnings sufficiency is then recalculated by subtracting the FICA taxes (Social Security and Medicare), adding the Earned Income Tax Credit, and subtracting work expenses to generate a measure of "expendable earnings." This recalculation changes the prevalence of earnings insufficiency more for some demographic groups than others. The demographic breakdown examines racial/ethnic groups, separates immigrant workers from the native born, divides gender groups by marital status and the presence of children and examines three age groups, four educational attainment groups, and three groups divided by metropolitan status. The wage rates of workers with insufficient earnings are assigned to wage bins tailored to current debates about minimum wages, finding that almost $25 \%$ of full-year full-time workers with insufficient expendable earnings have wages that exceed $\$ 15$ per hour, and that allocations into wage bins differ substantially among demographic groups.

Keywords: wage rates and poverty, demography of poverty wages

\section{INTRODUCTION}

Compared to other high-income countries, the United States places a strong emphasis on work-based poverty programs. The welfare reform of the 1990s ended AFDC, the entitlement to income support for families with children, and further emphasized work as a potential pathway out of poverty. Work requirements were established for some means-tested programs, and the Earned Income Tax Credit (EITC) was adjusted to further increase work incentives. Evidence suggests that these policies were "a revolution in poverty policy," increasing the work effort of the poor, especially single mothers (Hoynes, 2014). Nevertheless, the US has unusually high "in-work poverty rates" compared to other high-income countries (Brady et al, 2010).

Much of the interest in studies of poverty among workers is that it seems anomalous for a family with a full-year full-time worker to find itself unable to purchase the necessities built into the poverty thresholds. As will be clear from this study, however, there are problems of measurement that can lead to very different estimates of the prevalence of such anomalies. Two very recent pieces of research make the point. Burkhauser et al (2021) maintain that if one adopts the poverty standard of the original War on Poverty, accepts the Personal Consumption Expenditure index as the best measure of inflation, and employs an 
income measure that accounts for all benefits, poverty has been essentially eradicated, so the issue of poverty among workers is moot. On the other hand, Liu and Parilla (2021) claim that " $44 \%$ of U.S. families in 2019 did not earn an income that was high enough to cover their families' living expenses."

This paper adopts an approach that aims to measure the prevalence and demography of full-year fulltime workers whose earnings in 2018 or 2019 were insufficient to exceed the family poverty threshold employed in the calculation of the Supplemental Poverty Measure (SPM). This is somewhat different from measuring the prevalence and demography of the "working poor" because it focuses directly on the sufficiency of earnings (wages and salaries). In addition to that straightforward calculation, however, we recalculate earnings sufficiency by subtracting the FICA taxes (Social Security and Medicare), adding the Earned Income Tax Credit, and subtracting work expenses to generate a measure of "expendable earnings." This recalculation causes the prevalence of earnings insufficiency to rise by about $25 \%$ and affects some demographic groups more than others.

The paper begins with a review of the complex debate about how best to measure in-work poverty. It then explains the decisions we made in constructing this study and why we made them. The next section of the paper provides the basic results of our analysis, followed by a set of demographic breakdowns of earnings insufficiency, comparing our results to those commonly found by those who study in-work poverty. The last section expands the demographic analysis by putting the wage rates of workers with insufficient earnings into a set of wage bins tailored to current debates about minimum wages. That analysis shows that a substantial share (almost 20\%) of full-year full-time workers with insufficient earnings have wages that exceed $\$ 15$ per hour, and that these shares differ substantially among demographic groups.

\section{Measuring In-Work Poverty}

Understanding in-work poverty in America is not simple. In a comprehensive discussion of in-work poverty, Thiede, Lichter, and Sanders (2015) note that research on in-work poverty is complicated by measurement issues, leaving the resulting literature inchoate and undeveloped. To better understand poor workers, researchers must make fundamental decisions in four key areas which make comparisons across the literature difficult: defining the universe of potential workers, defining work effort and thus the pool of poor workers, defining income and poverty thresholds, and finally, defining the relevant unit of analysis.

The first issue is the survey data source. Studies of poverty in America usually rely on one of two survey datasets: the American Community Survey (ACS) and the Annual Social and Economic Supplement of the Current Population Survey (CPS-ASEC). The principal advantage of the ACS is its size. The ACS survey request is sent to approximately 295,000 households each month, generating an annual dataset of approximately 3.5 million households. The biggest advantage of its large size is the ability to make reliable estimates for relatively small geographical areas, though it also contains some unique questions. Its biggest disadvantage for our purposes is that it relies entirely on the Official Poverty Measure for its very limited poverty data. The CPS-ASEC is taken each year as a supplement to the monthly Current Population Survey. It is much smaller, about 75,000 households per year. Its biggest advantage is that it has been the source of data for official income and poverty data for decades, including the information required to ascertain poverty status using the Supplemental Poverty Measure. Detailed microdata for both of these datasets can be found at the source formally known as the Integrated Public Use Microdata Series, now known as by its former acronym, IPUMS. Additional data on in-work poverty can be drawn from panel datasets such as the National Longitudinal Survey of Youth (Van Winkle \& Struffolino, 2018), though the number of observations in panel datasets is generally much smaller than in the annual surveys.

The next issue is how to define the universe of potential workers. The most important decisions involve defining worker age limits and the relationship of potential workers to other family members. Many researchers focus on adults age 18 to 62 or 64 (Jensen, Findeis, Hsu \& Schachter, 1999; Jensen \& Slack, 2003; Slack \& Jessen, 2002), while others eliminate younger workers, partly as a means for excluding college-age workers (DeJong \& Madamba, 2001; Slack, 2010). Some studies (Hauan,Landale, and Leicht, 2000) focus only on male heads of households and their spouses, while others include all adult workers (Iceland and Kim, 2001; DeFina, 2007). 
The next measurement issue is the definition of work effort, thus defining the pool of "workers." Most researchers define the relevant sample based on hours and/or weeks worked. For example, several researchers study all workers who worked more than 27 weeks in the last year or who normally worked at least 35 hours per week in the last year (Caputo, 2007; Hauan et al., 2000; Lichtner et al., 1994; Slack, 2010), while others assign the designation of "worker" to any adult who worked at all (Thiede et al., 2017). Some researchers (Iceland and Kim, 2001 DeFina, 2007) combine weeks and hours to focus on 'full-year full-time' workers, a typical example being 1,750 hours or more in the previous year (35 hours per week X 50 weeks).

Defining the pool of relevant workers is only one of the key problems that researchers of in-work poverty must resolve. The calculation of a poverty rate requires the researcher to define a poverty threshold and exactly what is going to be compared to it. For example, if part-time workers are included in the pool of relevant workers, a decision must be made about whether or how to adjust their earnings to a full-time equivalent value to be compared to annual poverty thresholds. The researcher also must decide whether to deduct taxes and/or to add some or all benefits to the resource measure.

Once a measure of resources is created, it must be compared to a set of poverty thresholds. The measurement of poverty in the US has a contentious history (Citro \& Michael, 1995) involving criticisms of both the definition of income and the poverty thresholds used in the official US poverty measure. Nonetheless, some researchers use the official US poverty measure or some multiple of it (for example, $125 \%$ ), to study in-work poverty (Jensen et al., 1999; Jensen \& Slack, 2003; Slack \& Jensen, 2002; DeJong \& Madamba, 2001), while others (Iceland and Kim, 2001 DeFina, 2007) make use of the Supplemental Poverty Measure (Renwick and Fox, 2015). Yet others, particularly researchers who make cross-country comparisons, use a percentage of median income to determine poverty thresholds (Brady et al., 2010).

An additional problem in defining a set of thresholds is how best to compare workers who live in different family situations. While work is defined at the level of the individual, poverty is measured at the family or household level. Deciding the relevant unit of analysis involves assumptions about which family members are responsible for the economic well-being of the family and/or the degree of resource pooling in a household. Some researchers use individual income and poverty measures (Brady et al., 2010; Caputo, 2007) to answer the question of whether the worker's resources exceed a threshold appropriate for that individual. Studies which focus on family heads as primary earners use family-level income and poverty measures (Lichter et al., 1994; Slack, 2010), while Iceland and Kim (2010) and DeFina (2007) construct income at the household level and make use of a household measure of poverty. Assuming that the measure is a household measure, the poverty thresholds must be calculated using an equivalency scale adjusts for that household's size.

\section{This Study}

\section{Data Source}

Our data are drawn from the IPUMS CPS (Flood et al, 2020) samples taken in 2020 and 2019, which provide detailed work effort, income and poverty data for the previous year. The combined years provide data for slightly more than 380,000 adults.

\section{Defining Workers}

This study uses the individual worker as its unit of analysis. It focuses on household heads and their spouses/partners who work full time, defined as at least 35 hours a week, and full year, defined as at least 50 weeks out of the year. Though it is possible to impute a full-time equivalency for part-time workers, our focus is on the sufficiency of the wages earned by full-year full-time workers. We incorporate spouses and cohabiting partners rather than household heads alone because they are frequently the primary source of earnings. ${ }^{1}$ As is common among researchers we restrict the sample to workers whose earnings come primarily from wage and salaries. After these restrictions the dataset includes 98,396 observations. 


\section{Poverty Thresholds}

One of our contributions to the literature is our use of the Supplemental Poverty Measure (SPM) for the poverty thresholds based on recommendations by the National Academy of Sciences (Citro \& Michael, 1995).

In 1963 the U.S. official poverty measure (OPM) was devised by Mollie Orshansky, an employee of the Social Security Administration. To construct her measure, Orshansky used estimates of the cost of US Department of Agriculture's 1961 Economy Food Plan for families of different size and composition. Based on information in the 1955 Household Food Consumption Survey which suggested that the average family spent one third of their budget on food, Orshansky multiplied the cost of a family's economy food plan by three to get an estimate of the minimum level of family expenditures required to avoid poverty. The result was a series of 'poverty thresholds' based on the number and age of family members (for greater detail, see Fisher, 1997). A family was poor if their gross pre-tax income was less than their relevant poverty threshold. Despite widespread and persistent criticism, these thresholds (updated annually for changes in prices) and this definition of family resources describe how official poverty is calculated to this day.

In 1992 Congress charged the National Academy of Sciences to convene a panel of economists and policy makers to discuss alternative measures of poverty. The result was not one, but several Supplemental Poverty Measures (Citro \& Michael, 1995). Finally, in 2010 the US Census Bureau and Bureau of Labor Statistics began publishing a supplemental poverty measure (SPM). Though not a replacement for the OPM, it is widely viewed as a significant step forward in poverty measurement.

The SPM thresholds improve upon the OPM thresholds is several ways. First, the thresholds are based on mean expenditures on food, clothing, shelter, and utilities for all two-child consumer units in the $30^{\text {th }}$ to $36^{\text {th }}$ percentile range based on data from the Consumer Expenditure Survey, then multiplied by 1.2 to account for additional miscellaneous expenditures. These thresholds are then adjusted for geographic differences in housing costs by tenure, and a three-parameter equivalence scale is used to adjust for family size and composition. These thresholds are updated annually using a five-year moving average of expenditures on food, clothing, shelter, and utilities. As such, these thresholds are a "quasi-relative" measure of poverty since this adjustment process allows for changes in standard of living over time.

Second, the SPM measures use a revised measure of the "income" to be compared to the poverty threshold in determining poverty status. The OPM measure of resources is based entirely on cash income without accounting for the impact of both taxes paid and tax credits received. It also omits benefits that are paid in-kind, such as food stamps and housing vouchers.

The SPM, on the other hand, defines family resources as the sum of cash income from market and government sources plus government non-cash benefits received to meet a family's food, shelter, and utilities needs, minus taxes net of credits. In addition, work expenses, childcare expenses, out of pocket medical expenses and child support payments to another household are subtracted from this family resource measure, since these resources are not available to meet family needs (Blank, 2008).

The SPM measures also employ an updated concept of the family unit. The OPM defines a family as a group of individuals related by blood, marriage or adoption who share a residence. The SPM broadens the definition of 'family' to include unmarried partners and their relatives, co-resident unrelated children, and foster children (Provencher, 2011). Table 1 summarizes the key differences between the official and supplemental poverty measures. 


\section{TABLE 1 \\ COMPARISON OF THE OFFICIAL POVERTY MEASURE (OPM) AND THE SUPPLEMENTAL POVERTY MEASURE (SPM)}

\begin{tabular}{|c|c|c|}
\hline & Official Poverty Measure (OPM) & $\begin{array}{l}\text { Supplemental Poverty Measure } \\
\text { (SPM) }\end{array}$ \\
\hline Family Unit: & $\begin{array}{l}\text { Family head and relatives related } \\
\text { by marriage or adoption }\end{array}$ & $\begin{array}{l}\text { OPM family measure plus unrelated } \\
\text { children, foster children, unmarried } \\
\text { partners and their relatives }\end{array}$ \\
\hline Poverty Threshold & $\begin{array}{l}\text { Real value of } 3 \text { times the cost of } \\
\text { the } 1963 \text { thrifty food budget }\end{array}$ & $\begin{array}{l}\text { Real expenditures on food, clothing, } \\
\text { housing and utilities at } 30 \text { th- } 36 \text { th } \\
\text { percentile of } 2 \text {-child consumer families } \\
\text { multiplied by } 1.2 \text { for incidental } \\
\text { expenses }\end{array}$ \\
\hline $\begin{array}{l}\text { Threshold } \\
\text { Adjustments }\end{array}$ & $\begin{array}{l}\text { Varies by number of adults, } \\
\text { number of children, and age of } \\
\text { head }\end{array}$ & $\begin{array}{l}\text { Revised formula varies by number of } \\
\text { adults and number of children }\end{array}$ \\
\hline \multirow[t]{2}{*}{ Resource Measure } & \multirow{2}{*}{$\begin{array}{l}\text { Pre-tax income including cash } \\
\text { transfer payments }\end{array}$} & OPM resorce measure \\
\hline & & $\begin{array}{l}\text { Add: Tax credits and in-kind transfers } \\
\text { that pay for food, clothing, housing or } \\
\text { utilities } \\
\text { Subtract: Taxes paid, childcare } \\
\text { expenses, work expenses and out-of- } \\
\text { pocket medical expenses }\end{array}$ \\
\hline
\end{tabular}

Adapted from Renwick \& Fox (2016)

Though not adopted as the official measure of poverty, the Census Bureau has published the SPM annually since 2010 (Short, 2011-2015; Renwick and Fox, 2016), and a growing number of researchers are using the SPM to better understand poverty in the U.S. We make use of the some of the special features of the SPM thresholds and household resource calculations to better understand the levels of earnings and wages that are sufficient to exceed the SPM threshold of the worker's family.

\section{Earnings and Wages}

Our study uses two different measures of earnings. The first measure is standard in practically all studies of in-work poverty: "earnings" are defined as wage and salary income, and income from self-employment is not included. The wage rate can then be calculated by dividing annual earnings by the product of weeks worked (at least 50) and usual hours worked (at least 35). We also calculate an alternative definition of earnings by making three changes: 1) subtracting the worker's taxes paid for Social Security and Medicare, usually known as FICA; 2) adding the worker's Earned Income Tax Credit; and 3) subtracting the work expenses that are subtracted in the calculation of SPM poverty. We selected these three changes because they are all directly attached to work. We refer to the resulting value as "expendable earnings" and compare that result to the same SPM thresholds to measure the sufficiency of earnings.

\section{FICA Taxes and the Earned Income Tax Credit (EITC)}

To understand the effect of the FICA taxes and the Earned Income Tax Credit (EITC) on expendable earnings, it is useful to review a few details. The largest tax burden on the earnings of low-income families comes from the payroll tax that supports the Social Security (Old Age, Survivors and Disability) and Medicare systems. Combined they tax $7.65 \%$ of wage income paid to the worker, matched by a $6.2 \%$ payment paid directly by the employer. Collectively these taxes are often referred to as "FICA taxes," named after the Federal Insurance Contributions Act that levies them. 
Most low-income families pay little or no federal income taxes, and they often have negative income tax liabilities because of tax credits that exceed any income tax liability they might have. Some tax credits are "refundable," and others are not. While a non-refundable tax credit can reduce a family's tax liability to zero, a refundable tax credit that exceeds a taxpayer's liability, even if that liability is zero, provides a cash payment to the taxpayer. The Tax Policy Center (2020) estimates that in 2020, taxpayers in the lowest income quintile will, on average receive \$860, primarily due to the Earned Income Tax Credit and the Child Tax Credit.

The Earned Income Tax Credit (EITC) was created in 1975 as a refundable tax credit to increase work incentives and to offset the effect of the FICA taxes on low- and moderate-income working families. The credit rises over a range of earnings (phase-in range), is constant over a range of incomes, and is gradually phased out as earnings increase further. If the credit is greater than a family's tax liability, the balance is refunded. This rather complex calculation is summarized in the diagram below (Crandall-Hollick et al., 2021).

\section{FIGURE 1 \\ EITC AMOUNT BY NUMBER OF QUALIFYING CHILDREN, MARITAL STATUS, AND INCOME, 2020}

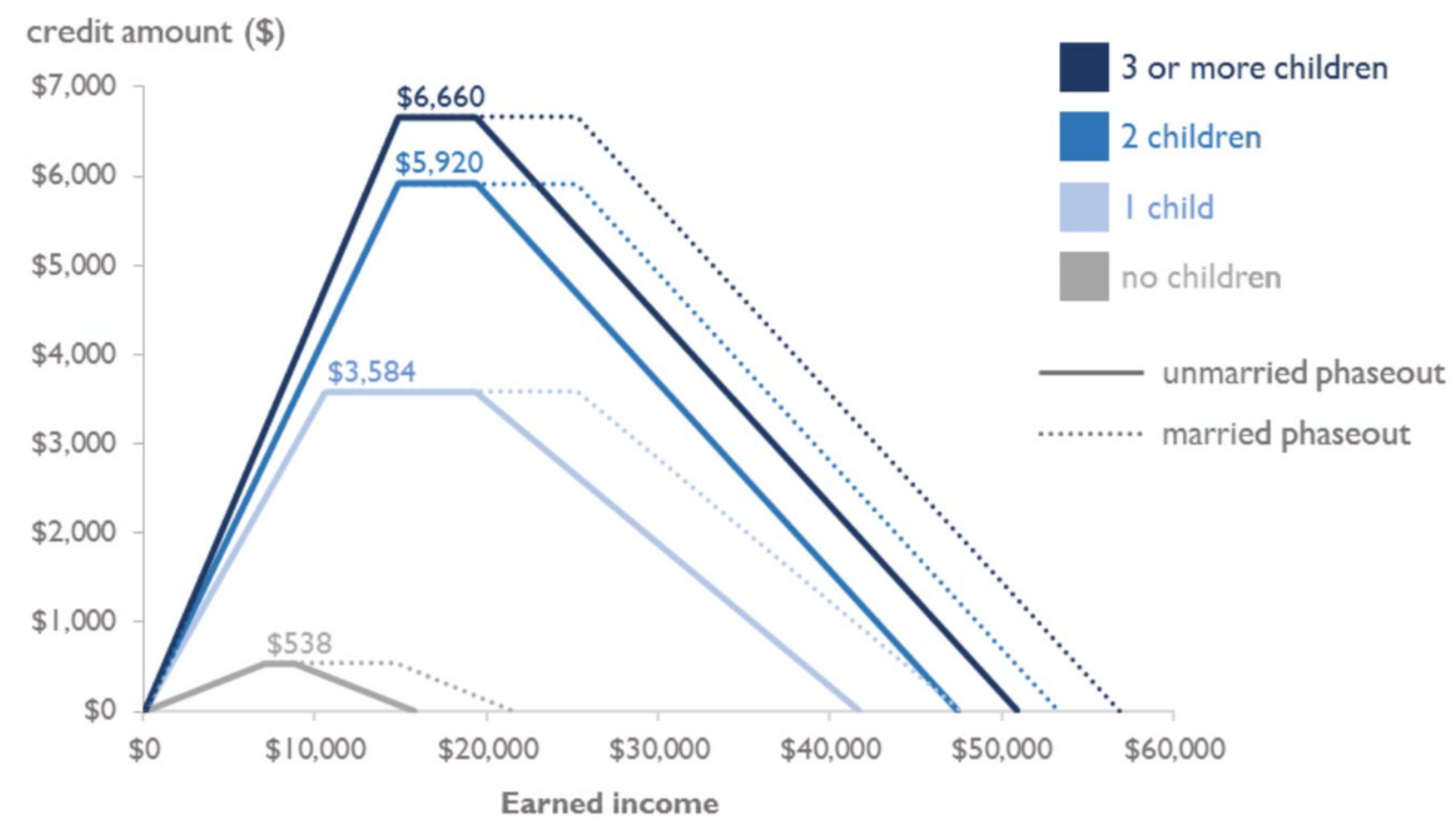

The first obvious conclusion from this diagram is that the credit for childless taxpayers is relatively small, a maximum of $\$ 538$ that phases out for incomes above $\$ 8,790$ for a single taxpayer or $\$ 14,680$ for a married couple filing jointly. The program is much more generous to workers with children, though the increase for each child is capped at a total of three children. The maximum credit amounts are $\$ 3,584$ for a 1-child family, $\$ 5,920$ for a 2-child family, and $\$ 6,660$ for a family with three or more children regardless of marital status. The notorious marriage penalty built into this structure can be most easily understood with an example: two single persons with earnings of $\$ 12,000$ each would each receive the maximum credit of $\$ 3,584$ for a total of $\$ 7,168$. If they were to marry with combined earnings of $\$ 24,000$, they would receive a credit of only $\$ 5,920$, and this penalty would become even larger once their combined incomes exceed $\$ 25,220$. Despite bipartisan efforts to alter this marriage penalty, it has not happened yet. 
Over the past 40 years numerous legislative changes have occurred before arriving at the EITC benefit structure used today. Recent changes have increased the size of the benefit for families with three or more children. While the benefit is targeted to single parents with children, recent changes have increased the benefit levels for workers with no qualifying children. Other legislation has changed eligibility rules for the EITC, reducing payments to some immigrant families by requiring filers to provide valid Social Security numbers for both adults and children. In addition to the federal EITC, states often have their own EITC programs, most modeled closely after the federal benefit, often as a percentage of the federal credit. As of July 2020, 23 states have their own EITC. We have not included state EITC benefits in calculating expendable earnings, as these payments are not recorded in the dataset. But even the federal EITC can add a significant amount to expendable earnings. For example, a $\$ 5,290$ credit for a 2-child family would add $\$ 3.02$ per hour to the expendable earnings of a worker who worked 50 weeks for 35 hours per week.

\section{Work Expenses}

It seems obvious that a worker's work expenses are not expendable on food, clothing, shelter or utilities, the components of the SPM threshold. Work expenses are imputed based on typical expenses on commuting, union dues, uniforms, and tools drawn from data compiled in the Survey of Income and Program Participation (SIPP). Based on results reported by Mohanty et al (2017), "typical" work expenses are about $\$ 48$ per week, of which approximately $94 \%$ are spent on transportation to and from work. If one assumes a 35-hour week, these expenses will reduce expendable earnings by $\$ 1.37$ per hour.

\section{Insufficiency}

We refer to a worker's earnings as "insufficient" if the total earnings of the full-year full-time worker are less than the family's SPM threshold, then we repeat the calculation using the worker's expendable earnings. The share of all eligible workers who have insufficient earnings will be called the "insufficiency rate." Since the sum of FICA taxes and work expenses is usually larger than the EITC, the insufficiency rate is usually larger when the calculation uses expendable earnings.

Insufficiency is not identical to in-work poverty. A family can have insufficient earnings but not be poor because the family has income other than earnings (self-employment earnings, social insurance, SNAP benefits, etc.). A family can also have sufficient earnings and still be SPM poor for various reasons, the most important being out-of-pocket medical expenses. The purpose of separating insufficiency from poverty is to focus on the issue of insufficient earnings with the goal of examining the range of wage rates associated with insufficiency.

TABLE 2

YEAR-ROUND, FULL-TIME WORKING HEADS, SPOUSES, OR COHABITATING PARTNERS WITH INSUFFICIENT EARNINGS BY POVERTY THRESHOLD

\begin{tabular}{lcc}
\hline & OPM Thresholds & SPM Thresholds \\
\hline Insufficiency Rate & $7.3 \%$ & $10.4 \%$ \\
Median Threshold & $\$ 25,926$ & $\$ 30,340$ \\
Mean Family Size & 4.24 & 4.10 \\
Median Wage & $\$ 9.21$ & $\$ 10.12$ \\
& & \\
Mean EITC & & $\$ 1,019$ \\
Mean FICA & & $\$ 1,710$ \\
Mean Work Expenses & & $\$ 1,923$ \\
\hline
\end{tabular}




\section{RESULTS}

\section{Insufficiency Rates}

The decision to employ the Supplemental Poverty Measure (SPM) thresholds rather than the Official Poverty Measure (OPM) thresholds was certain to increase the measured level of earnings insufficiency, and it did. As Table 2 shows, the OPM insufficiency rate for full-year full-time workers in 2018/19 was $7.3 \%$, while the SPM insufficiency rate was 10.4\%-- the measured rate increased by almost half. The increase was inevitable because of the difference in the threshold levels: the median threshold was pushed up from $\$ 25,926$ to $\$ 30,340$. This increase in the threshold could have been generated by an increased average family size, but it was not, as the mean family size of the sample below the SPM thresholds is slightly smaller than below the OPM thresholds. Rather, the increase is a consequence of the way in which the SPM threshold is measured, a quasi-relative measure driven by the cost of "necessities."

The insufficiency rate based on the OPM is smaller than the $4.5 \%$ working poor rate in 2018 reported by the Bureau of Labor Statistics (2020), the lowest rate in over 30 years. That rate is very similar to the $4.8 \%$ rate reported for a similar population in an earlier time period by Thiede et al (2015) for an earlier time period. ${ }^{2}$ As we pointed out in the description of our data, OPM poverty and earnings insufficiency are not identical concepts, because families with insufficient earnings may have cash income from other sources such as self-employment income or from social insurance such as unemployment insurance or disability insurance, and these sources may be received by family members other than the worker. Our analysis is focused entirely on the sufficiency of earnings.

With the idea of sufficient earnings in mind, we believe that the ability of a family to generate sufficient earnings through employment is more accurately measured if the earnings being compared to the threshold are recalculated to measure the earnings that are available to be expended. As previously discussed, we do this by adding the Earned Income Tax Credit (EITC), subtracting the FICA tax, and subtracting work expenses, resulting in what we call "expendable earnings." As Table 2 showed, the average FICA loss for those with insufficient earnings is slightly smaller than the EITC gain, but the main effect is that the average level of earnings is reduced by almost $\$ 2,000$ by work expenses. The consequences of this recalculation are shown in Table 3. The most important outcome is that the insufficiency rate is increased to $13.1 \%$-- almost $3 \%$ of the sample have their expendable earnings pulled below the SPM threshold by work-related taxes and work expenses despite the benefits from the EITC.

TABLE 3

SHARE OF YEAR-ROUND, FULL-TIME WORKING HEADS, SPOUSES, OR COHABITATING PARTNERS WITH INSUFFICIENT EARNINGS BY EARNINGS MEASURE AND DEMOGRAPHIC CHARACTERISTICS

\begin{tabular}{lcc}
\hline & Actual Earnings & Expendable Earnings \\
\hline ALL & $10.4 \%$ & \\
Insufficiency Rate & $\$ 30,340$ & $13.1 \%$ \\
Median Threshold & 4.10 & $\$ 29,720$ \\
Mean Family Size & & \\
\multicolumn{1}{c}{ Insufficiency Rate for Demographic Groups } \\
$\quad$ \\
Race, Ethnicity and Nativity & & \\
Non-Hispanic White Native-born & $6.1 \%$ & \\
Non-Hispanic Black Native-born & $\mathbf{1 1 . 7 \%}$ & $\mathbf{1 4 . 5 \%}$ \\
Hispanic Native-born & $\mathbf{1 4 . 2 \%}$ & $\mathbf{1 8 . 0 \%}$ \\
\hline
\end{tabular}




\begin{tabular}{lcc}
\hline Other Native-born & $\mathbf{1 0 . 7 \%}$ & $\mathbf{1 3 . 7 \%}$ \\
Hispanic Immigrant & $\mathbf{3 2 . 6 \%}$ & $\mathbf{3 7 . 7 \%}$ \\
Non-Hispanic Immigrant & $\mathbf{1 3 . 6 \%}$ & $\mathbf{1 6 . 7 \%}$ \\
Family Structure & & \\
Married Men with Children & $10.1 \%$ & $12.5 \%$ \\
Married Women with Children & $\mathbf{1 8 . 3 \%}$ & $\mathbf{2 3 . 0 \%}$ \\
Married Childless Men & $5.1 \%$ & $7.4 \%$ \\
Married Childless Women & $9.0 \%$ & $\mathbf{1 3 . 4 \%}$ \\
Unmarried Men with Children & $\mathbf{1 8 . 8 \%}$ & $\mathbf{2 2 . 2 \%}$ \\
Unmarried Women with Children & $\mathbf{2 3 . 5 \%}$ & $\mathbf{1 9 . 4 \%}$ \\
Unmarried Childless Men & $4.4 \%$ & $6.6 \%$ \\
Unmarried Childless Women & $6.2 \%$ & $9.2 \%$ \\
Age & & $\mathbf{2 6 . 7 \%}$ \\
Less than 25 years old & $\mathbf{2 0 . 6 \%}$ & $\mathbf{1 3 . 3 \%}$ \\
25-50 years old & $\mathbf{1 0 . 9 \%}$ & $11.4 \%$ \\
Over 50 years old & $8.5 \%$ & \\
Education & & $\mathbf{4 2 . 4 \%}$ \\
Less than High School & $\mathbf{3 7 . 3 \%}$ & $\mathbf{1 9 . 9 \%}$ \\
High School, No College & $\mathbf{1 6 . 1 \%}$ & $\mathbf{1 3 . 2 \%}$ \\
Some College & $10.1 \%$ & $5.6 \%$ \\
College Graduate & $4.0 \%$ & \\
Metropolitan Area & & $\mathbf{1 4 . 2 \%}$ \\
Non-Metropolitan & $9.1 \%$ & $12.3 \%$ \\
Small Metropolitan (<1 million) & $9.5 \%$ & $\mathbf{1 1 . 4 \%}$ \\
Large Metropolitan ( $>$ million) & & \\
\hline
\end{tabular}

\section{The Demography of Insufficiency Rates}

The lower panel of Table 3 shows the insufficiency rates for selected demographic groups. The groups with rates above the rate for the entire sample are indicated with bold-face type.

Our categories of race and ethnicity are more detailed than those that are usually employed because we want to emphasize the startlingly high insufficiency rates for Hispanic immigrants. The remainder of the race/ethnicity panel is easily summarized: Only native-born non-Hispanic Whites have an insufficiency rate lower than the national average. ${ }^{3}$

Our family status categories are also detailed. Those in families with children are the only family groups with double-digit insufficiency rates for actual earnings. The insufficiency rates of actual earnings among childless workers are always much higher for women than for men regardless of marital status, and married childless workers have higher insufficiency rates of actual earnings than singles.

Educational attainment and age are less frequently studied as correlates of in-work poverty, though the results are highly predictable. The in-work poverty rate among those without a high school diploma reported by the BLS in 2018 was $13.5 \%$. The insufficiency rate is much higher, with $37.3 \%$ of the workers without a high school diploma and $16.1 \%$ of those with only a high school diploma having insufficient actual earnings. The age breakdown of insufficiency rates has the same result as the BLS age breakdown of inwork poverty: it falls steadily with age. In interpreting this result it is important to remember that these are full-year full-time workers, excluding any semi-retired part-time workers.

The relationship between poverty and metropolitan status is often overlooked, in part because it is not a breakdown included in the BLS profiles. The reason why large metropolitan areas have relatively high 
insufficiency rates despite having relatively high wages is presumably a consequence of differences in thresholds due to differences in cost of living, a topic that is further addressed in the discussion of wage rates below.

\section{The Demography of Insufficient Expendable Earnings}

The demographic breakdown of insufficiency rates based on expendable earnings is shown in the second column of Table 3. For the overall population the insufficiency rate rises by about one-fourth ( 2.7 percentage points on a base of $10.4 \%$ ) when the rates are recalculated to reflect expendable earnings, and something like this ratio is found in most of the demographic groups.

The most obvious exception is that the "Unmarried Women with Children" group has a lower insufficiency rate when it is calculated with expendable earnings. A related observation is that childless workers have disproportionately large increases in the insufficiency rate calculated with expendable earnings. The reason for these exceptions is that unmarried women with children benefit most from the EITC and childless workers least, a topic that is further explored in the discussion of wage levels.

\section{The Demography of Wage Bins}

The implications of wage rate differentials depend in part on how wage rates are distributed. To gain a deeper understanding of the range of wage rates associated with insufficient earnings, we separate the wage rates into 4 "bins": less than $\$ 9$ per hour; $\$ 9-\$ 12$ per hour; $\$ 12-\$ 15$ per hour; and over $\$ 15$ per hour. The use of wage bins is not unique to this research; for example, wage bins are used by Hunt and Nunn (2019) in their study of wage polarization. In this case, however, we have selected the bins by tying them to values often seen in discussions of alternative values of the federal minimum wage and arrayed in $\$ 3$ increments to generate an approximate similarity of the bin sizes. The results are shown in Table 4.

TABLE 4

\section{SHARE OF YEAR-ROUND, FULL-TIME WORKING HEADS, SPOUSES, OR COHABITATING PARTNERS WITH INSUFFICIENT EARNINGS BY WAGE MEASURE AND DEMOGRAPHIC CHARACTERISTICS}

\begin{tabular}{lcccc}
\hline & $\begin{array}{c}\text { Share with } \\
\text { Wage }<\mathbf{\$ 9}\end{array}$ & $\begin{array}{c}\text { Share with } \\
\text { Wage }>=\$ 9 \\
\mathbf{8}<\mathbf{\$ 1 2}\end{array}$ & $\begin{array}{c}\text { Share with } \\
\text { Wage }>=\$ \mathbf{1 2} \\
\mathbf{8}<\mathbf{\$ 1 5}\end{array}$ & $\begin{array}{c}\text { Share with } \\
\text { Wage }>=\$ 15\end{array}$ \\
\hline All & $\mathbf{3 6 . 5 \%}$ & $\mathbf{2 7 . 0 \%}$ & $\mathbf{2 3 . 5 \%}$ & $\mathbf{1 3 . 1 \%}$ \\
Race, Ethnicity and Nativity & & & & \\
$\quad$ Non-Hispanic White Native-born & $\mathbf{4 4 . 5 \%}$ & $26.2 \%$ & $20.9 \%$ & $8.4 \%$ \\
$\quad$ Non-Hispanic Black Native-born & $\mathbf{4 6 . 3 \%}$ & $26.5 \%$ & $20.0 \%$ & $7.2 \%$ \\
Hispanic Native-born & $31.8 \%$ & $26.0 \%$ & $\mathbf{2 5 . 4 \%}$ & $\mathbf{1 6 . 8 \%}$ \\
Other Native-born & $34.3 \%$ & $20.5 \%$ & $\mathbf{2 6 . 6 \%}$ & $\mathbf{1 8 . 6 \%}$ \\
Hispanic Immigrant & $28.2 \%$ & $\mathbf{3 0 . 9 \%}$ & $\mathbf{2 6 . 1 \%}$ & $\mathbf{1 4 . 8 \%}$ \\
Non-Hispanic Immigrant & $28.2 \%$ & $24.8 \%$ & $\mathbf{2 5 . 1 \%}$ & $\mathbf{2 1 . 9 \%}$ \\
Family Structure & & & & \\
Married Men with Children & $25.3 \%$ & $26.6 \%$ & $\mathbf{2 9 . 4 \%}$ & $\mathbf{1 8 . 7 \%}$ \\
Married Women with Children & $28.9 \%$ & $\mathbf{3 1 . 2 \%}$ & $\mathbf{2 5 . 8 \%}$ & $\mathbf{1 4 . 1 \%}$ \\
Married Childless Men & $\mathbf{4 5 . 4 \%}$ & $20.5 \%$ & $20.0 \%$ & $\mathbf{1 4 . 1 \%}$ \\
Married Childless Women & $\mathbf{4 3 . 7 \%}$ & $\mathbf{2 7 . 9 \%}$ & $16.8 \%$ & $11.6 \%$ \\
Unmarried Men with Children & $31.1 \%$ & $\mathbf{2 8 . 8 \%}$ & $\mathbf{2 8 . 0 \%}$ & $12.1 \%$ \\
Unmarried Women with Children & $\mathbf{4 2 . 3 \%}$ & $\mathbf{2 9 . 5 \%}$ & $20.8 \%$ & $7.3 \%$ \\
Unmarried Childless Men & $\mathbf{6 3 . 1 \%}$ & $15.2 \%$ & $15.5 \%$ & $6.2 \%$ \\
Unmarried Childless Women & $\mathbf{6 3 . 4 \%}$ & $18.8 \%$ & $12.8 \%$ & $5.0 \%$ \\
\hline
\end{tabular}




\begin{tabular}{lcccc}
\hline Age & & & \\
$\quad$ Less than 25 years old & $\mathbf{5 5 . 2 \%}$ & $26.1 \%$ & $12.7 \%$ & $6.0 \%$ \\
25-50 years old & $33.9 \%$ & $\mathbf{2 8 . 1 \%}$ & $\mathbf{2 5 . 0} \%$ & $13.0 \%$ \\
$\quad \begin{array}{l}\text { Over 50 years old } \\
\text { Education }\end{array}$ & $\mathbf{3 8 . 6 \%}$ & $24.5 \%$ & $22.1 \%$ & $\mathbf{1 4 . 8 \%}$ \\
$\quad$ Less than High School & $34.0 \%$ & $\mathbf{3 2 . 3 \%}$ & $21.6 \%$ & $12.1 \%$ \\
$\quad$ High School, No College & $36.2 \%$ & $26.8 \%$ & $\mathbf{2 3 . 9 \%}$ & $13.1 \%$ \\
$\quad$ Some College & $34.1 \%$ & $26.7 \%$ & $26.0 \%$ & $\mathbf{1 3 . 2 \%}$ \\
$\quad$ College Graduate & $\mathbf{4 3 . 9 \%}$ & $21.3 \%$ & $20.8 \%$ & $\mathbf{1 4 . 0 \%}$ \\
Metropolitan Area & & & & \\
$\quad$ Non-Metropolitan & $\mathbf{5 0 . 8 \%}$ & $\mathbf{2 9 . 4 \%}$ & $16.9 \%$ & $2.9 \%$ \\
$\quad$ Small Metropolitan $(<1$ million) & $\mathbf{4 0 . 8 \%}$ & $\mathbf{2 7 . 5 \%}$ & $21.7 \%$ & $10.0 \%$ \\
$\quad$ Large Metropolitan (>1 million) & $29.9 \%$ & $26.0 \%$ & $\mathbf{2 6 . 4 \%}$ & $\mathbf{1 7 . 7 \%}$ \\
\hline
\end{tabular}

The first row of Table 4 shows the hourly wage rate bins of all full-year full-time workers with insufficient earnings. It is not very surprising that $36.5 \%$ of these workers earned less than $\$ 9$ per hour, not least because 29 states had minimum wages less than $\$ 9$ per hour in 2019. It is perhaps more surprising that almost the same number of workers with insufficient earnings $(36.6 \%)$ had a wage more than $\$ 12$ per hour. There were only three states with a $\$ 12$ minimum wage in 2019 (California, Massachusetts, and Washington), though a few cities, including Washington DC, had minimum wages above that level. Many full-year full-time workers had insufficient earnings despite receiving wages higher than any state was willing to require, and that was true even before consideration of the effect of employment-related taxes and work expenses.

The rest of Table 4 shows the distribution across wage bins for various demographic groups. The groups that are over-represented in a bin are indicated in bold-faced type. There are some results that are easy to predict. It is, for example, unsurprising that young workers and those who are both unmarried and childless (many of whom are young) have particularly low wage rates, and that married workers with children don't. It is likewise unsurprising that persons who have insufficient earnings despite having wage rates more than $\$ 15$ per hour often live in large metropolitan areas with a high cost of living. The biggest surprise is that over $40 \%$ of the native-born non-Hispanic White and Black workers are in the lowest wage bin and over $40 \%$ of the other four race/ethnic groups are in one of the two highest wage bins.

To explore these demographic differentials more fully, Table 5 presents the results of using expendable earnings as the measure of sufficiency. Since we already know that the population of those with insufficient expendable earnings is substantially larger $(13.1 \%$ of the workers rather than $10.4 \%)$, we would expect that the percentages in the high wage bins would become larger and the percentages in the low wage bins would become correspondingly smaller. In fact, the overall percentage in the over- $\$ 15$ bin rises by over 6 percentage points, from $13.1 \%$ to $19.4 \%$. and the percentage in the under- $\$ 9$ bin falls by over 5 percentage points, from $36.5 \%$ to $30.9 \%$. Similar changes appear in almost all the demographic groups. Of note, the native-born non-Hispanic White and Black groups, while still overrepresented in the under $\$ 9$ wage bin, have shares in all the under- $\$ 15$ wage bins that are more like the overall averages. 
TABLE 5

SHARE OF YEAR-ROUND, FULL-TIME WORKING HEADS, SPOUSES, OR COHABITATING PARTNERS WITH INSUFFICIENT EXPENDABLE EARNINGS BY WAGE MEASURE AND DEMOGRAPHIC CHARACTERISTICS

\begin{tabular}{|c|c|c|c|c|}
\hline & $\begin{array}{l}\text { Share with } \\
\text { Wage }<\$ 9\end{array}$ & $\begin{array}{c}\text { Share with } \\
\text { Wage }>=\$ 9 \\
\&<\$ 12\end{array}$ & $\begin{array}{c}\text { Share with } \\
\text { Wage }>=\$ 12 \\
\&<\$ 15\end{array}$ & $\begin{array}{c}\text { Share with } \\
\text { Wage }>=\$ 15\end{array}$ \\
\hline All & $30.9 \%$ & $24.8 \%$ & $24.9 \%$ & $19.4 \%$ \\
\hline \multicolumn{5}{|l|}{ Race, Ethnicity and Nativity } \\
\hline Non-Hispanic White Native-born & $35.1 \%$ & $24.8 \%$ & $24.9 \%$ & $15.2 \%$ \\
\hline Non-Hispanic Black Native-born & $42.2 \%$ & $25.1 \%$ & $20.4 \%$ & $12.3 \%$ \\
\hline Hispanic Native-born & $26.3 \%$ & $23.2 \%$ & $26.8 \%$ & $23.7 \%$ \\
\hline Other Native-born & $28.9 \%$ & $19.3 \%$ & $26.5 \%$ & $25.3 \%$ \\
\hline Hispanic Immigrant & $25.6 \%$ & $27.5 \%$ & $26.1 \%$ & $20.8 \%$ \\
\hline Non-Hispanic Immigrant & $24.6 \%$ & $22.6 \%$ & $23.9 \%$ & $28.9 \%$ \\
\hline \multicolumn{5}{|l|}{ Family Structure } \\
\hline Married Men with Children & $20.2 \%$ & $22.1 \%$ & $30.3 \%$ & $27.4 \%$ \\
\hline Married Women with Children & $22.6 \%$ & $26.1 \%$ & $29.0 \%$ & $22.3 \%$ \\
\hline Married Childless Men & $36.3 \%$ & $23.5 \%$ & $22.6 \%$ & $17.6 \%$ \\
\hline Married Childless Women & $35.9 \%$ & $28.9 \%$ & $18.2 \%$ & $17.0 \%$ \\
\hline Unmarried Men with Children & $25.5 \%$ & $26.7 \%$ & $31.3 \%$ & $16.5 \%$ \\
\hline Unmarried Women with Children & $41.1 \%$ & $25.5 \%$ & $21.2 \%$ & $12.2 \%$ \\
\hline Unmarried Childless Men & $55.3 \%$ & $20.4 \%$ & $15.4 \%$ & $8.9 \%$ \\
\hline Unmarried Childless Women & $56.1 \%$ & $22.8 \%$ & $14.1 \%$ & $7.0 \%$ \\
\hline \multicolumn{5}{|l|}{ Age } \\
\hline Less than 25 years old & $46.5 \%$ & $27.6 \%$ & $17.3 \%$ & $8.6 \%$ \\
\hline $25-50$ years old & $27.9 \%$ & $24.8 \%$ & $26.8 \%$ & $20.5 \%$ \\
\hline Over 50 years old & $33.4 \%$ & $23.8 \%$ & $22.9 \%$ & $19.9 \%$ \\
\hline \multicolumn{5}{|l|}{ Education } \\
\hline Less than High School & $30.7 \%$ & $30.3 \%$ & $22.7 \%$ & $16.3 \%$ \\
\hline High School, No College & $31.5 \%$ & $24.9 \%$ & $25.1 \%$ & $18.5 \%$ \\
\hline Some College & $28.0 \%$ & $24.3 \%$ & $27.6 \%$ & $20.1 \%$ \\
\hline College Graduate & $34.3 \%$ & $19.7 \%$ & $22.9 \%$ & $23.1 \%$ \\
\hline \multicolumn{5}{|l|}{ Metropolitan Area } \\
\hline Non-Metropolitan & $42.5 \%$ & $26.9 \%$ & $23.8 \%$ & $6.8 \%$ \\
\hline Small Metropolitan $(<1$ million $)$ & $34.2 \%$ & $25.6 \%$ & $24.8 \%$ & $15.4 \%$ \\
\hline Large Metropolitan (>1 million) & $25.5 \%$ & $23.6 \%$ & $25.7 \%$ & $25.2 \%$ \\
\hline
\end{tabular}

To assist in understanding the demographic differences in Table 5, it is useful to examine the group means of the three components of the expendable earnings calculation- earnings after FICA, the EITC, and 
work expenses- as well as the mean threshold to which expendable earnings are compared. These are shown in Table 6.

TABLE 6

YEAR-ROUND, FULL-TIME WORKING HEADS, SPOUSES, OR COHABITATING PARTNERS WITH INSUFFICIENT EXPENDABLE EARNINGS MEAN VALUES OF SELECT WORK-RELATED EXPENSES BY DEMOGRAPHIC CHARACTERISTICS

\begin{tabular}{|c|c|c|c|c|}
\hline & $\begin{array}{c}\text { Earnings net of } \\
\text { FICA }\end{array}$ & Threshold & EITC & $\begin{array}{c}\text { Work } \\
\text { Expenses }\end{array}$ \\
\hline All & $\$ 22,171$ & $\$ 30,732$ & $\$ 567$ & $\$ 1,943$ \\
\hline \multicolumn{5}{|l|}{ Race, Ethnicity and Nativity } \\
\hline Non-Hispanic White Native-born & $\$ 20,800$ & $\$ 27,403$ & $\$ 405$ & $\$ 1,929$ \\
\hline Non-Hispanic Black Native-born & $\$ 19,689$ & $\$ 26,962$ & $\$ 800$ & $\$ 1,921$ \\
\hline Hispanic Native-born & $\$ 23,380$ & $\$ 32,148$ & $\$ 606$ & $\$ 1,951$ \\
\hline Other Native-born & $\$ 23,780$ & $\$ 32,475$ & $\$ 560$ & $\$ 1,970$ \\
\hline Hispanic Immigrant & $\$ 23,224$ & $\$ 34,283$ & $\$ 770$ & $\$ 1,953$ \\
\hline Non-Hispanic Immigrant & $\$ 24,664$ & $\$ 35,300$ & $\$ 464$ & $\$ 1,967$ \\
\hline \multicolumn{5}{|l|}{ Family Structure } \\
\hline Married Men with Children & $\$ 25,392$ & $\$ 34,813$ & $\$ 730$ & $\$ 1,914$ \\
\hline Married Women with Children & $\$ 23,466$ & $\$ 32,588$ & $\$ 383$ & $\$ 1,977$ \\
\hline Married Childless Men & $\$ 21,299$ & $\$ 28,960$ & $\$ 108$ & $\$ 1,922$ \\
\hline Married Childless Women & $\$ 20,670$ & $\$ 27,791$ & $\$ 60$ & $\$ 1,981$ \\
\hline Unmarried Men with Children & $\$ 22,533$ & $\$ 32,196$ & $\$ 574$ & $\$ 1,902$ \\
\hline Unmarried Women with Children & $\$ 19,649$ & $\$ 31,062$ & $\$ 2,661$ & $\$ 1,926$ \\
\hline Unmarried Childless Men & $\$ 17,364$ & $\$ 23,180$ & $\$ 97$ & $\$ 1,913$ \\
\hline Unmarried Childless Women & $\$ 16,709$ & $\$ 22,187$ & $\$ 262$ & $\$ 1,941$ \\
\hline \multicolumn{5}{|l|}{ Age } \\
\hline Less than 25 years old & $\$ 18,154$ & $\$ 25,954$ & $\$ 476$ & $\$ 1,930$ \\
\hline $25-50$ years old & $\$ 22,680$ & $\$ 31,310$ & $\$ 699$ & $\$ 1,947$ \\
\hline Over 50 years old & $\$ 21,895$ & $\$ 30,464$ & $\$ 291$ & $\$ 1,938$ \\
\hline \multicolumn{5}{|l|}{ Education } \\
\hline Less than High School & $\$ 21,737$ & $\$ 33,151$ & $\$ 864$ & $\$ 1,928$ \\
\hline High School, No College & $\$ 22,013$ & $\$ 30,252$ & $\$ 598$ & $\$ 1,940$ \\
\hline Some College & $\$ 22,645$ & $\$ 30,084$ & $\$ 509$ & $\$ 1,953$ \\
\hline College Graduate & $\$ 22,222$ & $\$ 30,207$ & $\$ 298$ & $\$ 1,949$ \\
\hline \multicolumn{5}{|l|}{ Metropolitan Area } \\
\hline Non-Metropolitan & $\$ 19,046$ & $\$ 24,867$ & $\$ 550$ & $\$ 1,966$ \\
\hline Small Metropolitan $(<1$ million $)$ & $\$ 21,090$ & $\$ 28,689$ & $\$ 511$ & $\$ 1,911$ \\
\hline Large Metropolitan (>1 million) & $\$ 23,752$ & $\$ 33,708$ & $\$ 606$ & $\$ 1,956$ \\
\hline
\end{tabular}


The basic calculation tells us that any group that has higher earnings after FICA, a larger EITC, smaller work expenses, or a lower threshold will have a lower insufficiency rate, other things being equal. As an example, the native-born non-Hispanic White workers have low average earnings after FICA, as the wage bin results in Table 4 would lead us to expect, but they also have low thresholds and work expenses. The non-Hispanic Black workers are similar and have the largest EITC. Consequently, workers in these demographic groups have a substantial decrease in the share in the lowest wage bin and a substantial increase in the share in the highest wage bin when using the expendable earnings measure.

Earnings net of FICA often differ less across groups than one might expect. Only a few groups --Blacks, the young, the unmarried, and those who live outside of a metropolitan area-- have average earnings net of FICA less than $\$ 20,000$ (10\% lower than the overall average), and only two groups, non-Hispanic immigrants and married men with children, have earnings net of FICA above $\$ 24,000(10 \%$ higher than the overall average), though workers in large metropolitan areas come close. Mean annual work expenses are also similar across groups, all of which are within $\$ 35$ of the $\$ 1,943$ average. The range of values for the EITC is much broader, largely because the structure of the credit is targeted on parents, particularly unmarried parents, but the EITC is not large enough relative to earnings to make a substantial difference in the wage bin distributions. The largest and most important differences are among mean thresholds, as a high threshold can lead to insufficient earnings for workers with relatively high wages. Consequently, all the groups with a mean threshold above $\$ 32,000$ are over-represented in the over- $\$ 15$ wage bin, and all the groups with a mean threshold less than $\$ 29,000$ are over-represented in the under-\$9 wage bin.

\section{IMPLICATIONS}

We believe that the principal implications of this research can be drawn from the insufficiency rates for expendable earnings in Table 3 and the corresponding analysis of the wage bins in Table 5. The baseline result from Table 3 is that $13.1 \%$ of these full-year full-time workers did not have sufficient expendable earnings to support themselves and their families. There are, moreover, groups that had much higher insufficiency rates. It is disturbing that workers in every race/ethnic group except Non-Hispanic Whites had insufficiency rates above the national average, as did working single parents and workers who lack a college degree. Since these are all full-year full-time workers, these insufficiencies are not a consequence of the workers' work effort, but of the remuneration they receive from that work effort. The obvious next step is to question the sufficiency of their wage rates.

The median wage of workers with insufficient expendable earnings is $\$ 11.06$, but it is difficult to interpret that number without looking at the wage bin results in Table 5. In particular, it is important to note that almost $20 \%$ of those with insufficient earnings earn at least $\$ 15$ per hour. The presence of numerous workers with relatively high wages is common among Hispanic workers despite their high insufficiency rate, so one ought not conclude from that high insufficiency rate that the bulk of Hispanic workers with insufficient earnings have very low wages. A somewhat similar result appears for married women with children, who have a high insufficiency rate, but over $22 \%$ of them also earn more than $\$ 15$ per hour. Except for those married women with children, however, women with insufficient earnings are over-represented in the lower wage bins and would presumably benefit disproportionately from higher minimum wages or from changes in work rules that create conflicts between high-wage jobs and family responsibilities.

The results in Table 6 reveal another important implication: groups with high insufficiency rates generally have high thresholds. High thresholds have two drivers: larger families and locations with a higher cost of living. To some extent the EITC addresses differences in family size, though it would do so more effectively if it would do so more generously and with a smaller marriage penalty. The potential impact of insufficient earnings on child poverty emphasizes the importance of SNAP and school lunch programs that benefit larger families and reduce the impact of insufficient earnings on their food budgets. Differences in living costs are not as well addressed by federal programs. Given the importance of housing costs, full funding of federal housing programs could make a difference, especially for families in large metropolitan areas where average poverty thresholds exceed those in other areas by several thousand dollars per year. 
The mitigation of geographical poverty differentials is likely to be a persistent challenge in poverty policy for years to come.

\section{ENDNOTES}

1 Cohabiting partners are treated the same as spouses, the assumption being that income is shared in the family unit. The spouse or cohabiting partner earns more than the head in $38 \%$ of the families with earnings that are insufficient to escape poverty.

2 The samples differ somewhat from ours and from each other. The BLS Report includes all workers who worked for at least 27 weeks in 2018, while the workers in the Thiede et al (2015) study were restricted to family heads who worked at least 50 weeks in 2012.

3 Using a decomposition exercise similar to that used by Thiede et al (2017) we found that the low insufficiency rate of earnings for non-Hispanic whites is primarily attributable to differences in educational attainment and nativity.

\section{REFERENCES}

Blank, R.M. (2008). Presidential address: How to improve poverty measurement in the United States. Journal of the Association for Public Policy Analysis and Management, 27(2), 233-254.

Brady, D., Fullerton, A.S., \& Cross, J.M. (2010). More than just nickels and dimes: A cross-national analysis of working poverty in affluent democracies. Social Problems, 57(4), 559-585.

Burkhauser, R., Corinth, K., Elwell, J., \& Larrimore, J. (2021). Evaluating the success of President Johnson's war on poverty: Revisiting the Historical record using a full-income poverty measure. NBER Working Paper 26532.

Caputo, R.K. (2007). Working and poor: A panel study of maturing adults in the U.S. Families in Society, 88(3), 351-359.

Crandall-Hollick, M., Falk, G., \& Boyle, C.F. (2021). The earned income tax credit (EITC): How it works and who receives it. Congressional Research Service.

DeFina, R.H. (2007). A comparison of poverty trends and policy impacts for working families using different poverty indexes. Journal of Economic and Social Measurement, 32(2-3), 129-147.

DeJong, G.E., \& Madamba, A.B. (2001). A double disadvantage? Minority group, immigrant status, and underemployment in the United States. Social Science Quarterly, 82(1), 117-130.

Fisher, G.M. (1997). The development and history of the US poverty thresholds - A brief overview. GSS/SSS Newsletter, pp. 6-7.

Flood, S., King, M. Rodgers, R., Ruggles, S., \& Warren, J.R. (2020). Integrated Public Use Microdata Series. Current Population Survey: Version 7.0 [dataset].

Hoynes, H.W. (2014). A revolution in poverty policy: The earned income tax credit and the well-being of American families. Pathways, pp. 23-27.

Hauan, S.M., Landale, N.S., \& Leicht, K.T. (2000). Poverty and work effort among urban Latino men. Work and Occupations, 27(2), 188-22.

Iceland, J., \& Kim, J. (2001). Poverty among working families: New insights from an improved poverty measure. Social Science Quarterly, 82(2), 253-266.

Jensen, L., Findeis, J.L., Hsu, W., \& Schachter, J.P. (1999). Slipping into and out of underemployment: Another disadvantage for nonmetropolitan workers? Rural Sociology, 64(3), 417-438.

Jensen, L., \& Slack, T. (2003). Underemployment in America: Measurement and evidence. American Journal of Community Psychology, 32(1-2), 21-31.

Kenworthy, L., \& Marx, I. (2018). In-work poverty in the United States. In Handbook on In-Work Poverty. Edward Elgar Publishing.

Lichter, D.T., Johnston, G.M., \& McLaughlin, D.K. (1994). Changing linkages between work and poverty in rural America. Rural Sociology, 59(3), 395-415.

Liu, S., \& Perilla, J. (2021). How family-sustaining jobs can power an inclusive recovery in America's regional economies. Metropolitan Policy Program, Brookings Institution. 
Mohanty, A., Edwards, A., \& Fox, L. (2017). Measuring the cost of employment: Work-related expenses in the supplementary poverty measure. U.S. Census Bureau.

National Research Council. (1995). Measuring poverty: A new approach. Washington, D.C.: National Academy Press.

Provencher, A. (2011, August 2). Unit of analysis for poverty measurement: A comparison of the supplemental poverty measure and the official poverty measure. Census Bureau.

Renwick, T., \& Fox, L. (2016). The supplemental poverty measure: 2015. Current Population Reports, pp. 1-23.

Ross, M., \& Bateman, N. (2019). Meet the low-wage workforce. Metropolitan Policy Program, Brookings Institution.

Short, K.S. (2011-2015). The supplemental poverty measure: 2011, 2012, 2013, 2014, 2015. Current Population Reports 261, pp. 60-261.

Slack, T. (2010). Working poverty across the metro-nonmetro divide: A quarter century in perspective, 1979-2003. Rural Sociology, 75(3), 363-387.

Slack, T., \& Jensen, L. (2002). Race, ethnicity, and underemployment in nonmetropolitan America: A 30year profile. Rural Sociology, 67(2), 208-233.

Thiede, B.C., Lichter, D.T., \& Sanders, S.R. (2015). America's working poor: Conceptualization, measurement, and new estimates. Work and Occupations, 42(3), 267-312.

Thiede, B.C., Kim, H., \& Slack, T. (2017). Marriage, work, and racial inequalities in poverty: Evidence from the United States. Journal of Marriage and Family, 79(5), 1241-1257.

U.S. Bureau of Labor Statistics Report 1087. (2020). A Profile of the Working Poor, 2018.

Van Winkle, Z., \& Stroffolino, E. (2018). When working isn't enough: Family demographic processes and in-work poverty across the life course in the United States. Demographic Research, 39, 365379. 